\title{
TINGKAT EKSPLOITASI IKAN TUNA SIRIP BIRU SELATAN (Thunnus maccoyii) DI SAMUDERA HINDIA BERDASARKAN HASIL TANGKAPAN YANG DIDARATKAN DI PELABUHAN BENOA, BALI
}

\author{
Exploitation of Southern Bluefin Tuna(Thunnus maccoyii) on Hindia Ocean \\ based on fish catch, landed in Benoa Port, Denpasar, Bali.
}

\author{
Damar Nusawicaksono Kurniawan, Abdul Ghofar*), Suradi Wijaya Saputra, Bram Setyadji \\ Progam Studi Manajemen Sumberdaya Perairan, Departemen Sumberdaya Akuatik \\ Fakultas Perikanan dan Ilmu Kelautan, Universitas Diponegoro \\ J1. Prof. Soedarto, SH, Tembalang, Semarang, Jawa Tengah - 50275, Telp/Fax, +6224 7474698 \\ Email : damarnusa@yahoo.co.id
}

\begin{abstract}
ABSTRAK
Pengkajian dan pendugaan status sumberdaya perikanan di suatu wilayah perairan dapat dilakukan dengan mengetahui laju eksploitasinya. Data frekuensi panjang merupakan salah satu data yang dapat digunakan untuk melakukan pendugaan tingkat eksploitasi tersebut. Penelitian ini bertujuan untuk menduga nilai mortalitas, laju pertumbuhan, ukuran pertama kali tertangkap dan tingkat eksploitasi. Penelitian dilakukan pada bulan AprilMei 2016 di Loka Penelitian Perikanan Tuna Pelabuhan Benoa, Denpasar, Bali. Metode yang digunakan adalah metode survei. Sementara data panjang ikan tuna sirip biru selatan tahun 2013-2014 kemudian diolah dengan perangkat lunak FISAT II. Hasil penelitian menunjukkan struktur ukuran ikan tuna sirip biru selatan 145 - 210 cmFL dengan modus di ukuran 170-174 cmFL, ukuran pertama kali tertangkap $\left(\mathrm{L}_{\mathrm{c}}\right) 171 \mathrm{cmFL}$, hubungan panjang berat mendapat nilai $\mathrm{W}=0,00006^{*} \mathrm{FL}^{2,792}$, faktor kondisi berada pada angka 1,86-2,00, laju pertumbuhan yang didapat yaitu $\mathrm{L}_{\mathrm{t}}=220,50\left(1-\mathrm{e}^{0,2(\mathrm{t}+0,488)}\right)$, dimana nilai dari $\mathrm{L} \infty$ yaitu $220,50 \mathrm{cmFL}$ dan nilai $\mathrm{t}_{0}$ -0,49, laju mortalitas total (Z) sebesar 1,14/tahun, laju mortalitas alami (M) sebesar 0,36/tahun, dan laju mortalitas akibat penangkapan (F) sebesar 0,78/tahun, dan tingkat eksploitasi (E) 0,68/tahun, Hal ini menunjukan penangkapan ikan tuna sirip biru selatan oleh kapal rawai tuna di Samudera Hindia dalam keadaan berlebih (overfishing) karena nilai tingkat eksploitasi yang didapat melebihi tingkat pemanfaatan optimum atau $\mathrm{E}_{\mathrm{opt}}=0,5 /$ tahun $(0,68>0,5)$.
\end{abstract}

Kata Kunci : Ikan Tuna Sirip Biru Selatan, Tingkat Eksploitasi, Mortalitas, Pertumbuhan

\begin{abstract}
Stock assessment and prediction status of fisheries resources in the waters can be made by knowing the rate of exploitation. Length-frequency data is one can be used to suspect rate of exploitation . The aimed of this research was to suspect value of mortality, the growth rate, size at first capture and the level of exploitation. This research was conducted on April-May 2016 at the Loka Fishery Tuna's Research Benoa Port, Denpasar, Bali. This research used survey method. While data length of the southern bluefin tuna 2013-2014 was processed with FISAT II. The results showed size structure of southern bluefin tuna 145-210 cmFL with mode in sizes 170-174 cmFL, size at first capture (Lc) $171 \mathrm{cmFL}$, value of lenght and weight relationship W $=0,00006 *, 792$ FL2, condition factors 1,86-2.00, the growth rate $\mathrm{Lt}=220,50(1-\mathrm{e}$ of $0.2(\mathrm{t}+0,488))$, where the value of $\mathrm{L} \infty$ was $220.50 \mathrm{cmFL}$ and value t0 -0.49 total mortality rate $(\mathrm{Z})$ of $1.14 /$ year, rate of natural mortality (M) of $0.36 /$ year, and rate of mortality due to the arrest of $(\mathrm{F})$ amounted to $0.78 /$ year, and the rate of exploitation $(\mathrm{E})$ 0,68 /year, it shows the fishing of southern bluefin tuna by the longline in the Indian Ocean was overfishing because level of exploitation value was over the optimum effort or Eopt $=0,5 /$ year $(0.68>0.5)$.
\end{abstract}

Keyword: Southern Bluefin Tuna, exploitation rate, Mortality, growth,

*) Penulis penanggungjawab

${ }^{\circ}$ Copyright by Management of Aquatic Resources (MAQUARES) 


\section{PENDAHULUAN}

Perairan Indonesia yang terletak diantara dua samudera, menjadikannya sebagai jalur migrasi dandaerah penangkapan bagi berbagai jenis ikan.Hal ini didukung dalam Sjarif et al. (2012), Indonesia merupakan salah satu wilayah penangkapan armada rawai tuna yang memiliki sumberdaya melimpah.Daerah penangkapan meliputi perairan Samudera Hindia dari selatan Pulau Sumba dan perairan Samudera Pasifik dari utara Halmahera hingga utara Papua.Menurut Nurhakim et al. (2007), daerah penangkapan kapal-kapal yang berbasis di Benoa meliputi perairan Selatan Jawa, Bali dan barat Sumatera dilakukan oleh kapal 30-200 GT, sedangkan kapal-kapal > 200GT kadang-kadang beroperasi sampai ke Selatan Nusa tenggara, laut Flores dan Laut Banda.Salah satu ikan ekonomis penting yang memiliki jalur migrasi melewati perairan Indonesia adalah ikan tuna sirip biru selatan atau southern bluefin tuna (Thunnus maccoyii).

Pelabuhan Benoa merupakan pelabuhan utama di Provinsi Bali dan menjadi salah satu basis pangkalan pendaratan ikan tuna di Indonesia selain Muara Baru (Jakarta), Pelabuhan Ratu (Jawa Barat) dan Cilacap (Jawa Tengah). Sebagai salah satu pelabuhan utama perikanan tuna, Pelabuhan Benoa menjadi basis pangkalan kapalkapal penangkap ikan tuna berskala industri yang beroperasi di perairan Samudera Hindia.Berdasarkan data Asosiasi TunaLongline Indonesia (2012), kapal rawai tuna di Benoa yang tercatat menjadi anggota asosiasi tersebut berjumlah 693 kapal.Diduga jumlah kapal rawai tuna yang beroperasi di seluruh perairan Indonesia sekitar 1400 it, dimana sekitar 1.200 unit beroperasi di Samudera Hindia (Pusat Riset Perikanan Tangkap, 2002).

Seiring dengan tingkat eksplotasi yang terus meningkat, sumberdaya ikan tuna di Samudera Hindia terus menurun, salah satu indikatornya adalah penurunan hasil tangkapan perupaya (CPUE) secara global dari tahun ke tahun dengan tingkat eksploitasi sudah mencapai padat tangkap (fully exploited) (IOTC, 2002).Pada tahun 1995 tercatat bahwa rata-rata berat ikan tuna yang tertangkap $132 \mathrm{~kg}$, laju tangkap 0,86 dan CPUE 2800 kg/trip, menurun menjadi rata-rata berat ikan $129 \mathrm{~kg}$, laju tangkap 0,45 dan CPUE $1720 \mathrm{~kg} /$ trip pada tahun 2005 (Pusat Riset Perikanan Tangkap, 2002).Data mengenai tangkapan tertinggi ikan tuna sirip biru selatan terjadi pada bulan Maret 2014 (198,32 ton) dan terendah pada April 2014 (49,61 ton). Diduga musim puncak pemijahan ikan ini terjadi pada Maret 2014 dan akhir musim pemijahan pada April 2014, sehingga mayoritas kapal rawai tuna mendapat hasil tangkapan sirip biru tertinggi pada maret 2014 (Sulistyaningsih et al. 2014). Data penangkapan tuna sirip biru selatan menunjukkan dua puncak dalam hal hasil tangkapan. Pertama pada bulan September - Oktober dan kedua pada bulan Februari - Maret, hal ini menunjukkan beberapa derajat sinkroni dalam sebuah proses pemijahan (Farley \&Davis ,1998).

Penelitian ini penting dilakukan karena potensi yang dimiliki Indonesia sangat bagus sebagai salah satu jalur migrasi ikan tuna sirip biru selatan. Salah satu spesies dari ikan tuna ini merupakan target yang bisa mendatangkan uang banyak dalam segi bisnis perikanan. Semakin bertambahnya hari, tekanan eksploitasi ikan tuna sirip biru selatan semakin besar dan berpotensi untuk mengganggu kelestarian ikan tersebut.Hal ini bisa dilihat dari hasil tangkapan yang semakin turun dan perbedaan ukuran yang semakin kecil.Penelitian ini bisa menjadi salah satu pedoman dalam menentukan langkah pengelolaan perikanan yang berkelanjutan dengan menghitung laju eksploitasi ikan tuna sirip biru selatan.

\section{MATERI DAN METODE PENELITIAN}

\section{A. Waktu dan Tempat}

Penelitian dilaksanakan pada bulan April-Mei 2016 di Pelabuhan Benoa, Bali dan analisis data dan penyusunan laporan dilakukan bekerja sama dengan Loka Penelitian Perikanan Tuna (LP2T) Benoa Bali.

\section{B. Pengumpulan data}

Metode yang dilakukan yaitu survei, metode ini dilaksanakan secara primer dan sekunder. Data primer yaitu data pengukuran panjang ikan (FL) dengan alat kaliper ketelitian 0,5 cm dan pengukuran berat ikan yang telah dibersihkan insang dan isi perutnya dengan timbangan digital ketelititian $0,1 \mathrm{~kg}$. Data sekunder dipeoleh dari Laboratorium Data Loka Penelitian Perikanan Tuna yaitu data hasil tangkapan ikan tuna sirip biru selatan yang didaratkan di Pelabuhan Benoa Bali tahun 2013 - 2014. Data hasil tangkapan bulan April-mei kemudian disajikan dalam bentuk grafik struktur ukuran.

\section{Analisis Data}

a) Hubungan panjang berat dan faktor kondisi

Analisis hubungan panjang berat dilakukan dengan mengikuti persamaan :

Keterangan :

$$
\mathrm{W}=\mathrm{aL}^{\mathrm{b}}
$$

$\mathrm{W}=$ Berat ikan tanpa insang dan isi perut/ GGT $(\mathrm{kg})$

$\mathrm{L} \quad=$ Panjang cagak ikan/ FL $(\mathrm{cm})$

a $\quad=$ Intercept

${ }^{\circ}$ Copyright by Management of Aquatic Resources (MAQUARES) 
$\mathrm{b} \quad=$ Slope

Nilai b yang sama dengan 3 berarti hubungan panjang berat isometrik $(b=3)$, dan untuk nilai $b$ yang tidak sama dengan 3 berarti hubungan panjang berat allometrik $(b \neq)$

Menurut Effendie (2002), perhitungan faktor kondisi berdasarkan hubungan panjang berat menggunakan rumus $\mathrm{W}=\mathrm{aLb}$ dan hasil alometrik, maka perhitungan faktor kondisi dapat menggunakan faktor kondisi relatif $(\mathrm{Kn})$ yang dirumuskan:

Keterangan :

$$
K n=\mathrm{W} / \mathrm{aL}^{\mathrm{b}}
$$

$\mathrm{Kn} \quad$ : faktor kondisi dalam berat total

$\mathrm{W}$ : berat rata-rata ikan $(\mathrm{g})$

$\mathrm{aL}^{\mathrm{b}} \quad$ : Panjang rata-rata ikan $(\mathrm{cm})$

b) Ukuran pertama kali tertangkap

Angka pecahan hasil tranformasi jumlah individu setiap kelas panjang diakumulasi dari nilai tengah terkecil sampai terbesar, nilai tengah terbesar dinamakan SL. Lajur lain dari nilai ini dibuat dengan nilai Ln (1/SL-1). Analisis regresi Ln (1/SL-1) $=\mathrm{S} 1-\mathrm{S} 2 * \mathrm{~L}$ dibuat dengan hubungan Ln (1/SL-1) sebagai (y) dengan mid-lenght sebagai (x). Nilai Lc = S1/S2 dari a dan b yang menghasilkan S1 dan S2 (Hartati et al., 2011).

c) Parameter pertumbuhan

Parameter pertumbuhan diolah dengan rumus Pauly (1984) yang diolah dengan ELEVAN I (electro length frequency analysis) di perangkat lunak FISAT II:

$$
\mathrm{L} \infty=\mathrm{Lmaks} / 0,95
$$

Pendugaan persamaan Von Bertalanffy menggunakan metode Plot Ford-Walford dengan interval waktu pengambilan contoh yang sama (Sparre dan Veneme, 1999) :

Keterangan:

$$
\mathrm{L}_{\mathrm{t}}=\mathrm{L} \infty\left(1-\mathrm{e}^{-\mathrm{k}(\mathrm{t}-\mathrm{t})}\right)
$$

$\mathrm{L}_{\mathrm{t}} \quad=$ prediksi panjang ikan pada saat umur $\mathrm{t}$

$\mathrm{L} \infty \quad=$ panjang tak terhingga (panjang infinity)

$\mathrm{K}=$ indeks kurva pertumbuhan, waktu yang dibutuhkan untuk mencapai $\mathrm{L} \infty$

$\mathrm{t}_{0} \quad=$ umur teoritis pada saat panjang ikan nol

d) Laju mortalitas dan laju eksploitasi

Laju mortalitas alami (M) diolah dengan persamaan yang dikemukakan Pauly (1979):

$$
\text { Ln } \mathrm{M}=-0,0152-0,279 * \operatorname{Ln} \mathrm{L} \infty+0,653 * \operatorname{Ln} \mathrm{K}+0,463 * \operatorname{Ln} \mathrm{T}
$$

Keterangan:

$\mathrm{M} \quad=$ mortalitas alami

$\mathrm{L} \infty \quad=$ panjang asimtotik pada persamaan pertumbuhan vonBertalanffy

$\mathrm{K}=$ koefisien pertumbuhan pada persamaan pertumbuhan von Bertalanffy

$\mathrm{T} \quad=$ rata-rata suhu lingkungan perairan $28,56^{\circ}\left({ }^{\circ} \mathrm{C}\right)$ (Yuniarti et al., 2013)

Laju mortalitas total $(\mathrm{Z})$ dihitung dengan konversi kurva hasil tangkapan ke data panjang atau persamaan Jones dan van Zalinge (Sparee, 1999):

Keterangan:

$$
\operatorname{Ln} \mathrm{C}(\mathrm{L}, \mathrm{L} \infty)=\alpha+\mathrm{Z} / \mathrm{K} * \mathrm{Ln}(\mathrm{L} \infty-\mathrm{L})
$$

$$
\begin{array}{ll}
\mathrm{Ln} C(\mathrm{~L}, \mathrm{~L} \infty) & =\text { hasil tangkapan kumulatif } \\
\alpha & =\text { Intercept } \\
\mathrm{Z} / \mathrm{K}(\mathrm{b}) & =\text { Koefisien regresi }
\end{array}
$$

Laju mortalitas penangkapan diketahui dengan mengurangi mortalitas total (Z) dengan mortalitas alami (M) atau $\mathrm{F}=\mathrm{Z}$ - M. Persamaan yang digunakan untuk menhitung mortalitas alami dan mortalitas total telah dikemas dalam perangkat lunak FISAT II.

\section{HASIL DAN PEMBAHASAN}

A. Hasil

a) Struktur ukuran

Ikan tuna sirip biru selatan yang didaratkan di Pelabuhan Benoa Bali pada bulan April-Mei berjumlah 302 ekor. Struktur ukuran yang didapat berada pada 145- $210 \mathrm{cmFL}$. Ukuran ikan yang paling banyak tertangkap berada pada kisaran 170 - $174 \mathrm{cmFL}$, yaitu sebanyak 71 ekor, sedangkan ukuran ikan yang paling sedikit tertangkap yaitu $149 \mathrm{cmFL}$ dan $210 \mathrm{cmFL}$ masing-masing hanya 1 ekor (Gambar 1). 


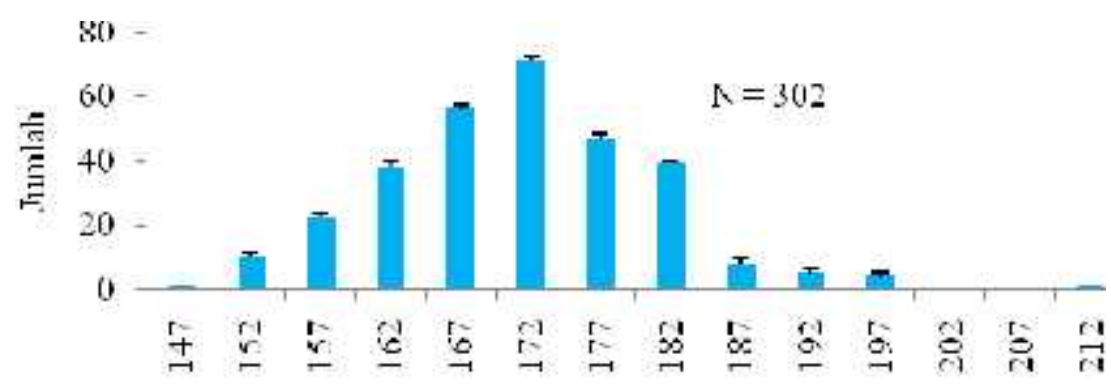

Paliane ( $\mathbf{L}$ )

b)

Gambar 1. Struktur ukuran ikan tuna sirip biru selatandi Pelabuhan Benoa bulan April-Mei 2016

\section{Hubungan panjang berat dan faktor kondisi}

Hasil analisis hubungan panjang berat yang dilakukan memperoleh persamaan $\mathrm{W}=0,00006 * \mathrm{FL}^{2,792}$ Uji t yang dilakukan pada data dengan selang kepercayaan $95 \%$ terhadap nilai $b=2,792$. Hasil uji $\mathrm{T}$ mendapatkan hasil $\mathrm{T}_{\text {hit }} 2,154$ dan $\mathrm{T}_{\text {tab }} 1,97$ yang berarti tolak $\mathrm{H} 0$ karena $\mathrm{T}_{\text {hit }}>\mathrm{T}_{\text {tab. }}$ Pola pertumbuhan ikan tuna sirip biru selatan bersifat allometrik negatif, yaitu kondisi dimana pertambahan panjang lebih cepat dari pertambahan berat. Hubungan panjang berat disajikan dalam Gambar 2:

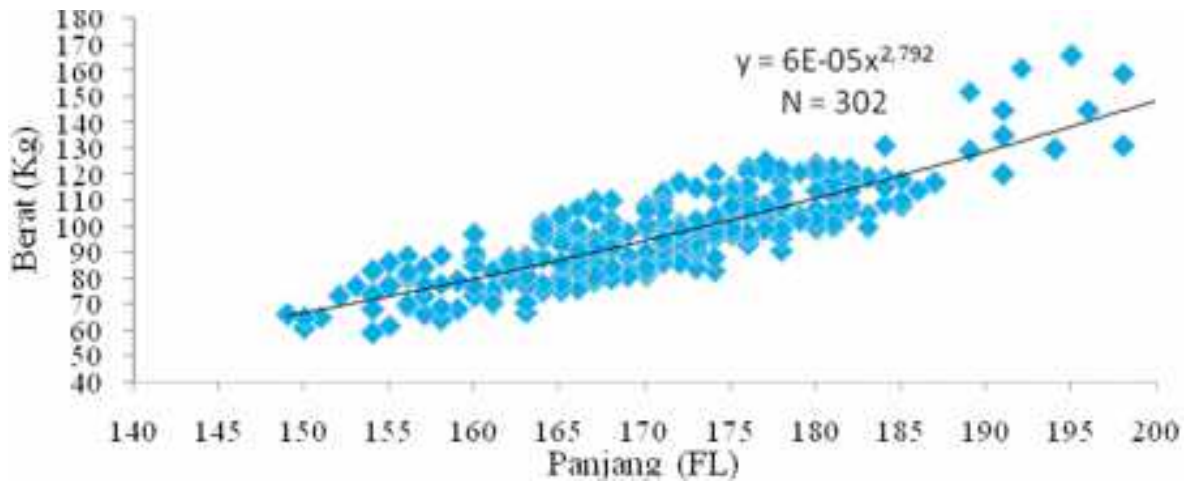

Gambar 2. Struktur ukuran ikan tuna sirip biru selatandi Pelabuhan Benoa bulan April-Mei 2016

Analisis faktor kondisi yang dilakukan terhadap ikan tuna sirip biru selatan yang didaratkan di Pelabuhan Benoa pada bulan April - Mei didapat nilai rata-rata 1,94. Faktor kondisi paling rendah berada pada interval $210-214 \mathrm{cmFL}$ yaitu 1,86 , sedangkan nilai tertinggi pada interval $145-149$ dan $155-159 \mathrm{cmFL}$ yaitu 2,00.Nilai faktor kondisi disajikan dalam Gambar 3:

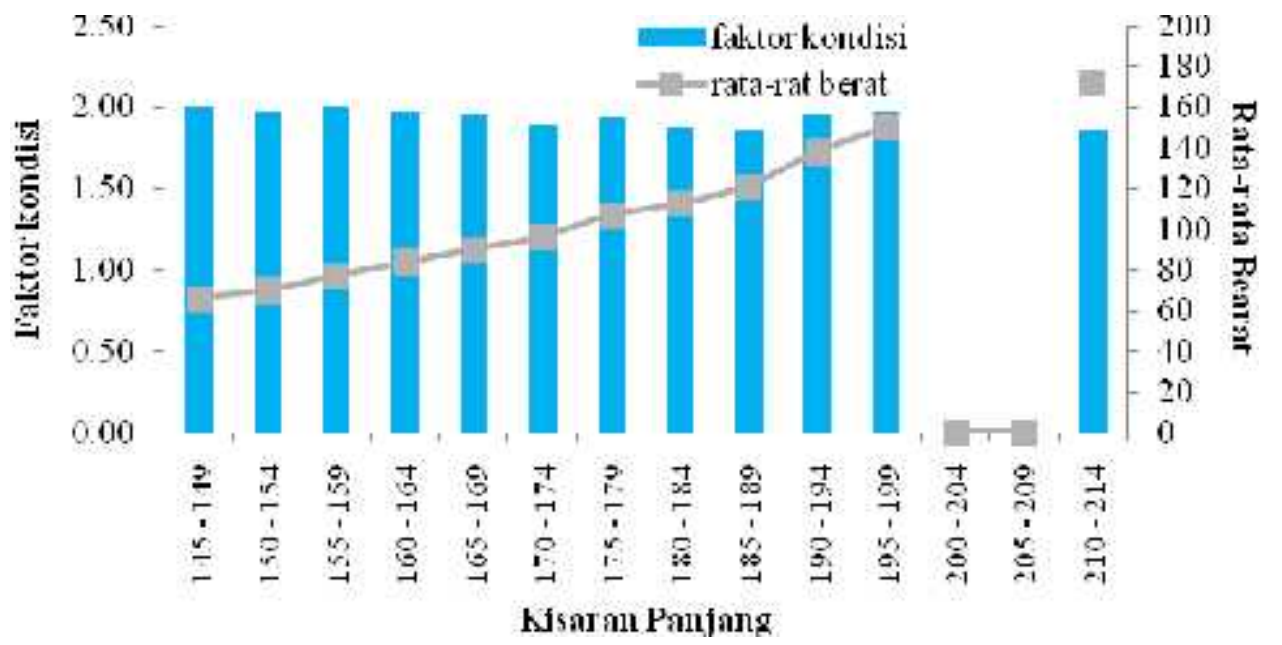

Gambar 3. Faktor kondisi ikan tuna sirip biru selatandi Pelabuhan Benoa bulan April-Mei 2016

c) Ukuran pertama kali tertangkap

Hasil analisis ukuran pertama kali tertangkap ikan tuna sirip biru selatan yang didaratkan di Pelabuhan Benoa Bali berada pada angka $171 \mathrm{cmFL}$, ukuran ini berada pada kelas 170-174 cmFL dimana kelas ini menjadi modus ukuran rata-rata ikan tuna sirip biru selatan tertangkap. Grafik ukuran ikan pertama kali tertangkap disajikan Gambar 4:

\footnotetext{
${ }^{\circ}$ Copyright by Management of Aquatic Resources (MAQUARES)
} 


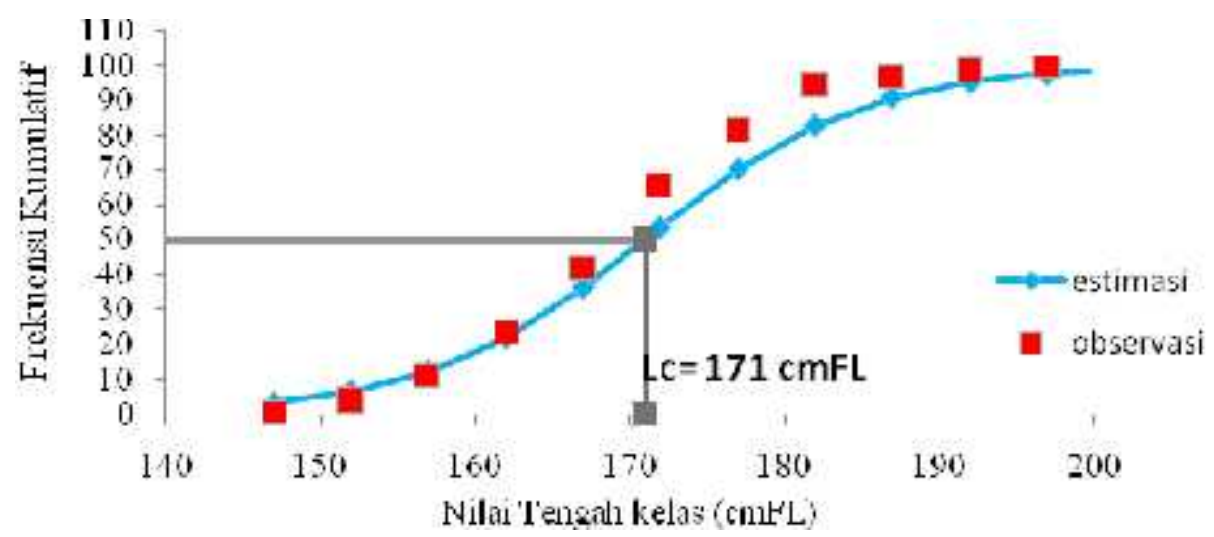

Gambar 4. Ukuran pertama kali tertangkap ikan tuna sirip biru selatandi Pelabuhan Benoa bulan April-Mei 2016

d)

\section{Parameter Pertumbuhan}

Pendugaan parameter pertumbuhan yang dilakukan dengan perangkat lunak Fisat II mendapatkan nilai $\mathrm{L}_{\infty}=220,50 \mathrm{cmFL}$. Sementara nilai $\mathrm{K}$ atau koefisien pertumbuhan adalah 0,2 tahun ${ }^{-1}$. Kedua nilai ini kemudian digunakan untuk menghitung nilai $\mathrm{t}_{0}$, dan ditemukan nilai $\mathrm{t}_{0}=-0,49$. Pertumbuhan panjang ika tuna sirip biru selatan yang didaratkan di Pelabuhan Benoa Bali disajikan dalam Gambar 5:

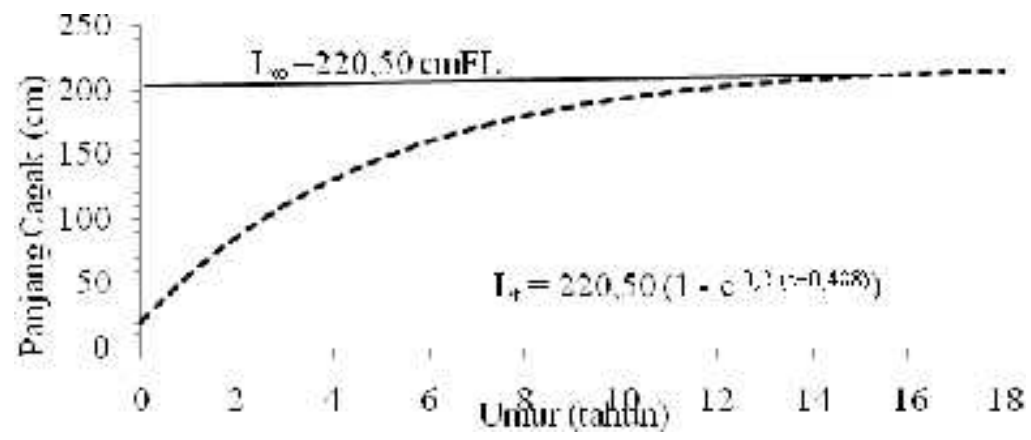

Gambar 5. Grafik pertumbuhan ikan tuna sirip biru selatandi Pelabuhan Benoa 2013-2014

Grafik Von Bertalanffy (Gambar 6) menunjukan proses rekruitmen (masuknya kelompok umur baru) paling banyak terjadi di bulan April dan November 2014.

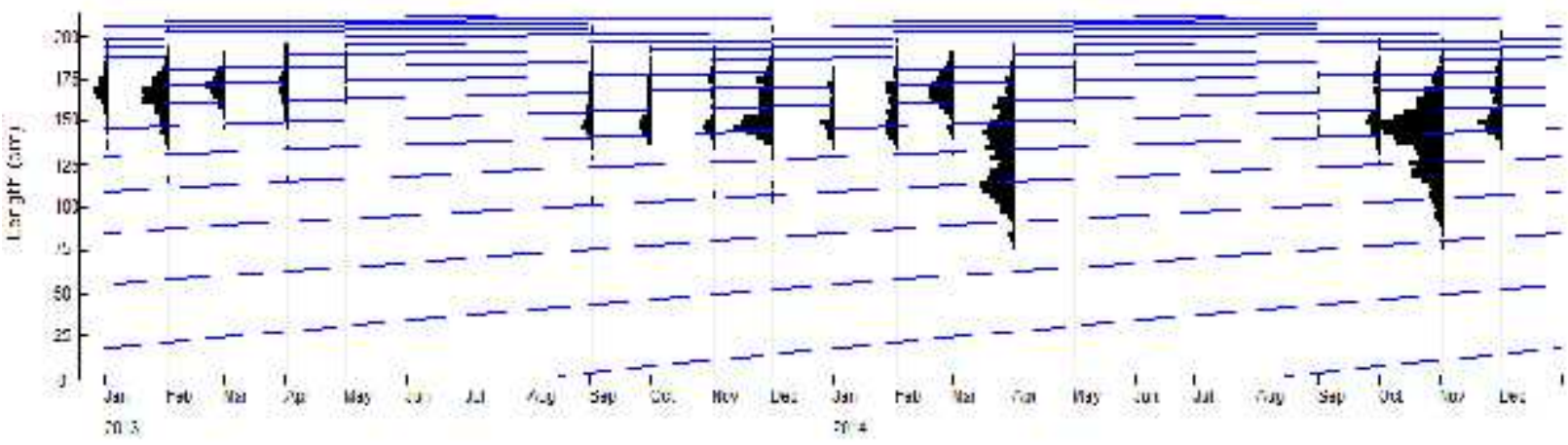

Gambar 6. Grafik Von Bertalanffy ikan tuna sirip biru selatandi Pelabuhan Benoa 2013-2014

e)

\section{Laju mortalitas dan laju eksploitasi}

Laju Mortalitas alami (M) yang didapat berada pada angka 0,36/tahun dan laju mortalitas karena penangkapan berada pada angka 0,78/tahun. Kedua nilai ini dicari dengan perangkat lunak FISAT II. Sementara itu nilai mortalitas total dapat dicari dengan cara yang relatif mudah jika sudah mendapat nilai mortalitas keduanya, Mortalitas total yang didapat yaitu 1,14/tahun.

Kondisi perikanan di suatu wilayah didapat dengan mengetahui pendugaan laju eksploitasi di wilayah tersebut. Status perikanan diduga berada pada kondisi overfishing bila tingkat eksploitasi sudah melebihi batas

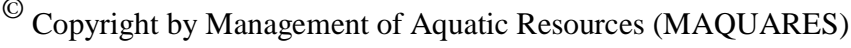


pemanfaatan optimum $\left(\mathrm{E}_{\mathrm{opt}}\right)$ sebesar 0,5. Sementara hasil analisis tingkat eksploitasi yang didapat pada penelitian ini yaitu 0,68. Laju mortalitas dan laju eksploitasi disajikan dalam gambar 7:

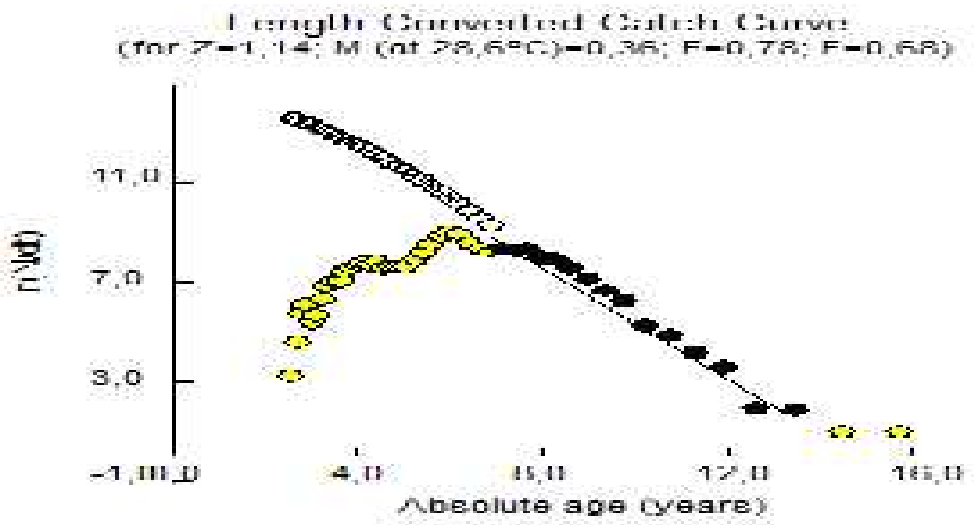

Gambar 7. Grafik mortalitas dan eksploitasi ikan tuna sirip biru selatandi Pelabuhan Benoa 2013-2014

\section{B. Pembahasan}

\section{a) Struktur ukuran}

Jumlah sampel yang diperoleh pada saat pengambilan data panjang ikan tuna sirip biru selatan selama bulan April-Mei yaitu 302 ekor di kisaran ukuran 145- $210 \mathrm{cmFL}$. Hasil sampling tersebut tidak berbeda jauh dengan penelitian yang dilakukan Loka Penelitian Perikanan Tuna (LPPT), dijelaskan bahwa rata-rata ukuran ikan tuna sirip biru selatan yang didaratkan di pelabuhan Benoa tahun 2010 berada pada kisaran nilai tengah $170 \mathrm{cmFL}$ dan proporsi ukuran utama atau ukuran paling dominan berkisar pada 160-180 cmFL yang didapat dari jumlah sampling 1251 ekor ikan tuna sirip biru selatan (LPPT, 2011).

Terjadinya penurunan ukuran ikan tuna sirip biru selatan yang didaratkan di Pelabuhan Benoa diduga akibat dari tekanan eksploitasi yang cenderung meningkatdi Samudera Hindia khususnya, baik penangkapan di daerah pemijahan atau di daerah juvenil.Farley et al.(2007) menjelaskan bahwa rata-rata distribusi ukuran ikan tuna sirip biru selatan di Samudera Hindia cenderung menurun sampai ukuran 188 cmFL di tahun 1993/1994. Sementara Naamin (1999)dalam Mahrus (2012), mengemukakan bahwa ukuran ikan tuna sirip biru selatan yang didaratkan di pelabuhan Benoa selama periode sampling tahun 1995-1996 dengan mendapatkan data ukuran panjang berkisar antara 147-221 cmFL dengan nilai tengah $184 \mathrm{cmFL}$. Farley et al. (2007) menjelaskan pada 2002/2003 ukuran ini berfluktuasi antara $168 \mathrm{cmFL}$ sampai $171 \mathrm{cmFL}$ dan bisa dibilang mengalami penurunan ukuran

\section{b) Hubungan panjang berat dan faktor kondisi}

Dari analisis diperoleh persamaan $\mathrm{W}=0,00006 * \mathrm{FL} 2,792$. Nilai koefisien regresi (nilai b dari uji $t$ ) ini menunjukan pola pertumbuhan yang terjadi yaitu allometrik negatif, dimana pertumbuhan panjangnya lebih cepat daripada pertumbuhan berat. Mahrus (2012), menyatakan nilai koefisien regresi merupakan ukuran kesesuaian (goodness of fit) garis regresi terhadap suatu data.Penelitian yang dilakukan oleh Jen-Chieh Shiao et al.(2007), menunjukan perbedaan pola pertumbuhan ikan tuna sirip biru selatan pada daerah penangkapan kapal longline Taiwan di perairan Samudera Hindia mendapat nilai b>3 menunjukkan allometrik positif atau pertumbuhan berat lebih cepat dari pertumbuhan panjangnya. Nilai ini ditunjukkan dengan formula hubungan antar panjang dan berat yaitu $\mathrm{W}=0,0000070 \mathrm{FL} 3,161$ dengan nilai koefisien regresi $\mathrm{R} 2=0,922$ dengan jumlah sampel 4008.

Faktor kondisi yang didapat pada penelitian ini yaitu 1,86 sampai 2,00. Nilai ini menunjukan bentuk ikan gemuk ataukah kurus. Kelompok ikan yang memiliki nilai faktor kondisi tinggi dapat diduga memiliki kondisi lingkungan yang sesuai untuk spawning yang berhubungan dengan proses rekruitmen. Hasil yang didapat menunjukan ikan tuna sirip biru selatan yang menjadi sampel berada pada kondisi kurus atau kurang gemuk karena nilai faktor kondisi dibawah 3. Hal ini diduga karena terdapat perbedaan umur, tingkat kematangan gonad, kondisi lingkungan dan ketersediaan pakan di perairan tersebut. Hal ini diduakung dalan Effendie (2002), nilai faktor kondisi akan bervariasi tergantung dari kepadatan populasi, tingkat kematangan gonad, makanan, jenis kelamin dan umur ikan. Ikan yang didapat pada saat penelitian memiliki kondisi kurus diduga terjadi karena musim penangkapan pada bulan April-Mei sudah jauh dari puncak musim dimana pada bulan tersebut bukan masa spawning ikan tuna sirip biru selatan.

c) Ukuran pertama kali tertangkap

Pengelolaan sumberdaya perikanan menggunakan hasil pendugaan ukuran ikan pertama kali tertangkap sebagai salah satu pertimbangan. Hal ini terkait dengan proses regenerasi ikan, dimana ikan yang belum matang gonad sudah tertangkap akan mempengaruhi proses tersebut. Jika hal ini terjadi terus menerus, bukan tidak mungkin spesies tuna sirip biru selatan lama kelamaan akan punah. Collette dan Nauen (1983) berpendapat,

\footnotetext{
${ }^{\circ}$ Copyright by Management of Aquatic Resources (MAQUARES)
} 
ukuran matang gonad atau Lenght of first maturity diperkirakan berada pada ukuran $130 \mathrm{cmFL}$, atau setara dengan $40 \mathrm{~kg}$ berat ikan tuna sirip biru selatan. Hal ini menunjukkan bahwa rata-rata ikan yang didapat saat sampling bulan April-Mei 2016 telah memenuhi syarat ukuran ikan layak tangkap, karena lebih besar dari ukuran ikan pertama kali matang gonad ( $\mathrm{Lc}>\mathrm{Lm})$.

d) Parameter Pertumbuhan

Analisis data panjang yang dilakukan menggunakan perangkat lunak FISAT II mendapatkan nilai $\mathrm{L} \infty=$ 220,50 cmFL, sedangkan nilai K yang didapat adalah 0,200/tahun-1.Nilai L $\infty$ menunjukkan ukuran maksimal panjang ikan bisa tumbuh sampai ukuran tersebut, Nilai K dapat diartikan sebagai angka pendugaan pertumbuhan ikan setiap tahunnnya. Ikan tuna sirip biru selatan jika sudah mencapai ukuran maksimal masih tetap hidup tetapi tidak akan mengalami pertambahan panjang melainkan menjadi pertambahan berat. Hasil penelitian berbeda dengan penelitian Thorogood (1987), dijelaskan bahwa hasil yang didapat dari sampel ikan tuna sirip biru selatan yang tertangkap di Samudera Hindia tahun 1980-an didapatkan nilai L $\infty 261,3 \mathrm{cmFL}$ dan nilai $\mathrm{K}$ sebesar 0,108 . Perbedaan yang terdapat pada kedua nilai pendugaan $\mathrm{L} \infty$ dan $\mathrm{K}$ biasanya diakibatkan komposisi sampel ikan tuna sirip biru selatan yang didapat lebih didominasi ikan muda (younger fish) atau ukuran ikan sampel lebih kecil dari penelitian lain (Yukinawa, 1970).

e) Laju mortalitas dan laju eksploitasi

Tingkat mortalitas karena penangkapan lebih besar dari mortalitas alami. Hal ini menunjukan bahwa tingkat penangkapan dan eksploitasi lebih tinggi dari laju mortalitas alami. Jika hal seperti ini terus terjadi dan selalu bertambah setiap tahun, bukan tidak mungkin ikan tuna sirip biru selatan akan mengalami kepunahan mengingat status ikan yang saat ini sudah mengalami overfishing. Menurut Gulland (1971) bahwa suatu sumberdaya yang dieksploitasi dalam kondisi optimum apabila nilai F = M, yaitu Eopt = 0,5. Pollacheck (2002), menjelaskan bahwa mortalitas karena penangkapan yang berlebihan dan menyebabkan semakin meningkatnya tekanan eksploitasi dapat berdampak ke peluang individu tuna sirip biru selatan untuk menjadi ukuran besar.

Kondisi suatu perairan dapat diduga dengan mengetahui tingkat eksploitasi daerah tersebut, seberapa besar tingkat eksploitasi bila dibanding daya maksimal atau potensi maksimal wilayah tersebut. Tingkat eksplotasi ikan tuna sirip biru selatan yang didaratkan di pelabuhan Benoa Denpasar pada tahun 2013-2014 berada pada kisaran 0,68 (>0,5). Hal ini harusnya menjadi perhatian lebih karena tingkat eksploitasi sudah melebihi tingkat pemanfaatan optimum. Selain ikan tuna sirip biru selatan di Samudera Hindia yang telah melebihi tingkat eksploitasi, ikan tuna sirip biru di Samuderas Pasifik juga mengalami keadaan yang sama. Hal ini juga sempat dibahas pada pertemuan Convention on International Trade in Endangered Species on Wild Fauna And Flora (CITIES) pada tahun 1992, bahwa ikan tuna sirip biru di Samudera Pasifik merupakan salah satu species yang nyaris punah karena tingkat pemanfaatan atau penangkapan yang berlebihan. Murphy \& Majkowski (1981), sebagai negara yang sudah lama menangkap ikan tuna sirip biru selatan, Australia, Jepang dan Selandia Baru sepakat bahwa kondisi stok ikan tuna sirip biru selatan dalam keadaan fully exploited yang memiliki pengertian kenaikan upaya penangkapan tidak akam menambah jumlah tangkapan.

\section{KESIMPULAN}

Berdasarkan analisis hubungan panjang berat didapatkan bahwa pola pertumbuhan ikan tuna sirip biru selatan adalah allometrik negatif, yaitu keadaan dimana pertumbuhan panjang lebih cepat dari pertambahan berat dengan persamaan $\mathrm{W}=0,00006 * \mathrm{FL}^{2,792}$.Struktur ukuran ikan tuna sirip biru selatan yang didaratkan di pelabuhan Benoa pada bulan April - Mei 2016 yaitu antara 145 - $210 \mathrm{cmFL}$, sedangkan dari data sekunder tahun 2013 - 2014 berada pada kisaran ukuran 70 - 210 cmFL.Ikan tuna sirip biru selatan yang tertangkap rawai tuna di Samudera Hindia memiliki ukuran pertama kali tertangkap (Lc) $171 \mathrm{cmFL}$. Parameter pertumbuhan yang didapt yaitu $\mathrm{Lt}=220,50(1$ - e $0,2(\mathrm{t}+0,488))$, dimana nilai dari $\mathrm{L} \infty$ yaitu 220,50 cmFL dan nilai t0 $-0,49$.

Laju mortalitas total (Z) sebesar 1,14/tahun dengan laju mortalitas alami (M) sebesar 0,36/tahun, dan laju mortalitas akibat penangkapan (F) sebesar 0,78/tahun, yang berarti kematian ikan tuna sirip biru selatan diduga lebih banyak disebabkan karena penangkapan.Tingkat eksploitasi (E) ikan tuna sirip biru selatan diketahui 0,68/tahun, dimana nilai ini telah melebihi batas optimum pemanfaatan dan bisa dikatakan kondisi penangkapan ikan ini overfishing atau berlebih.

\section{UCAPAN TERIMAKASIH}

Penyusunan penelitian ini lancer karena bantuan dari berbagai pihak baik secara langsung maupun tidak, penulis mengucapkan terima kasih kepada:

1. Bapak Budi Nugraha, S.Pi, M.Si, selaku Kepala Loka Penelitian Perikanan Tuna dan seluruh enumerator dari LP2T yang telah membantu dalam pengumpulan data selama penelitian berlangsung

3. Seluruh pihak yang membantu jalannya penelitian ini termasuk keluarga besar mahasiswa Manajemen Sumberdaya Perairan 2012 Universitas Diponegoro. 


\section{DAFTAR PUSTAKA}

Collette, B.B. \& C.E. Nauen. (1983). FAO Species Catalogue Vol. 2. Scombrids of the world. An annotated and Illustrated catalogue of tunas, mackerels, bonitos and related species known to date. FAO Fish. Synop. 125(2):137p. Rome:FAO

Effendie. 2002. Biologi Perikanan. Yayasan Pustaka Nusantara, Yogyakarta.

Farley, J. H. \& Davis T. L. O. 1998. Reproductive Dynamics of Southern Bluefin Tuna, Thunnus maccoyii. Fishery BuIletin. 96(2): 223-236.

Farley, J., R Andamari \& C. Proctor. 2007. Update on the Lenght and Age Distribution of SBT in the Inonesian Longline catch. CCSBT-ESC/0709/10.

Farley, J.H, T.L.O. Davis, J.S. Gunn, N.P. Clear \& A.L Preece. 2007 b. Demographic Pattern of Southern Bluefin Tuna, Thunnus maccoyii, as Inferred from Direct Age Data. Journal Elsevier : Fisheries Reseach $83: 151-161$.

Gulland, J. A. 1971. The fish resources of the oceans. FAO Fishing News (Books) Ltd. Surrey: 255pp.

Hartati, T., Suwarsono, M. Taufik. 2011. Komposisi Ukuran, Tingkat Kematangan Gonad, dan Mkanan Ikan Banyar di Perairan Kendari. Balai Penelitian Perikanan Laut, Jakarta; 209 - 226.

LPPT. 2011. Laporan Enumerasi Tahun 2010., 1 - 19.

Mahrus. 2012. Distribusi Ukuran Panjang dan Berat Tuna Sirip Biru Selatan (Thunnus macoyii Castelnau, 1972) yang Tertangkap dari Perairan Samudera Hindia dan Didaratkan di Pelabuhan Benoa Bali. [Tesis]. Program Magister Ilmu Kelautan, Universitas Indonesia, Depok, 59 hlm.

Nurhakim, S., VPH. Nikijuluw., D. Nogroho., \& BD. Prisantoso,. 2007. Status Perikanan Menurut Wilayah Pengelolaan. Pusat Riset Perikanan Tangkap.

Pauly, D. 1979. A New Methodology for Rapidly Acuaring Basic Information on Tropical Fih Stock: Growth, Mortality, and Stock Recruitmen Relationship in Tropical Small Scale Fisheries, Proe. International Workshop, Sept., 12 - 19, U.R.I., Kingston; 154 - 172.

1984. Fish Population Dynamic in Tropical Waters: A manual for Use With Programmable Calculators. ICLARM, Manila.

Polacheck, T. 2002. Experimental Cathes and the Precautionary approach : The Southern Bluefin Tuna Dispute. Marine Policy 26 : 283-294

Pusat Riset Perikanan Tangkap. 2002. Analisis Pengelolaan Perikanan Tuna di Samudera Hindia dan Perikanan Perairan Umum di Sumatera Barat. Laporan Teknis Tahun Anggaran 2002. Pusat Riset Perikanan Tangkap. Badan Riset Kelautan dan Perikanan. Departemen Kelautan dan Perikanan. Jakarta.

Shiao, J.H., Chang, S.K., Lin, Y.T., dan Tzeng, W.N. 2007. Size and Age Composition of Southern Bluefin tuna (Thunnus maccoyii) in the central Indian Ocean Inferred from Fisheries and Otolith data. Zoological Studies. 47(2): 158-171.

Sjarif, B., Suwardiyono, S. D. Gautama. 2012. Penangkapan dan Penanganan Ikan Tuna Segar di Kapal Rawai Tuna. Balai Besar Pengembangan Penangkapan Ikan, Semarang; 60 - 61

Sparre, P., and S.C.Venema. 1999. Introduksi pengkajian stok ikan tropis buku-I manual (Edisi Terjemahan). Kerjasama Organisasi Pangan, Perserikatan Bangsa-Bangsa dengan Pusat Penelitian dan Pengembangan Perikanan, Badan Penelitian dan Pengembangan Pertanian. Jakarta. 438 hlm.

Sulistyaningsih, R.K., Arief,W., Budi, N. 2014. Distribusi Panjang dan Estimasi Total Tangkapan Tuna Sirip biru Selatan (Thunnus maccoyii) pada Musim Pemijahan di Samudera Hindia. Jurnal Penelitian Perikanan Indonesia Volume 20 tahun 2014. Pusat Penelitian Pengelolaan Perikanan dan Konservasi Sumber Daya Ikan. Jakarta. Hal 215-224.

Thorogood, J., 1987. Age and growth rate determination of southern bluefintuna, Thunnus maccoyii, using otolith banding. J. Fish. Biol. 30, 7-14.

Yukinawa, M. (1970). Age and Growth of the Southern Bluefin Tuna (Thunnus maccoyii ) (Castelnau) by Use of Scale. Bull. Far Seas Fish Res. Lab. 3,229-257.

Yuniarti, A., L. Maslukah, dan M. Helmi. 2013. Studi Variabilitas Suhu Permukaan Laut Berdasarkan Citra Satelit Aqua Modis Tahun 2007 - 2011 di Perairan Selat Bali. Jurnal Oseanografi. 2(4): 416 - 421. 